Ks. Mirosław Twardowski*

Uniwersytet Rzeszowski

\title{
WIARA W STWORZENIE A TEORIA EWOLUCJI: KONFLIKT CZY SYMBIOZA? DEBATA ,SCHÜLERKREIS” JOSEPHA RATZINGERA NAD RELACJĄ STWORZENIE - EWOLUCJA
}

Stowa klucze:

stworzenie, ewolucja, „Schülerkreis”

Treść:

I. „Schülerkreis” o relacji stworzenie - ewolucja na tle nauczania Kościoła

II. Debata „Schülerkreis” o relacji stworzenie - ewolucja

1. Kardynała Christopha Schönborna próba „uwolnienia” Darwina $\mathrm{z}$ darwinizmu

2. „Boska informacja zakodowana w stworzeniu” - ujęcie Roberta Spaemanna

3. „Przypadek czy cel w procesie ewolucji?” - stanowisko Paula Erbricha

4. „Ewolucja nie wymaga zewnętrznej interwencji” - ujęcie Petera Schustera

III. Ocena wkładu „Schülerkreis” w debatę o relacji stworzenie - ewolucja

Ewolucja to temat żywo interesujący Kościół katolicki. Od lat wewnątrz Kościoła, a także poza nim, toczy się dyskusja wokół zagadnień związanych $\mathrm{z}$ teorią ewolucji i jej relacją do wiary w ingerencję stwórczą Boga. Debata stworzenie - ewolucja zyskała na sile po opublikowaniu w lipcu 2005 roku w The New York Times artykułu kard. Christopha Schönborna pt. Odnajdywanie zamystu $w$ przyrodzie (tyt. oryg. Finding

${ }^{*}$ Ks. Mirosław Twardowski, dr filozofii, adiunkt w Zakładzie Polityki Regionalnej i Gospodarki Żywnościowej Wydziału Biologiczno-Rolniczego Uniwersytetu Rzeszowskiego, wykładowca filozofii przyrody w Wyższym Seminarium Duchownym w Rzeszowie. 
Design in Nature) ${ }^{1}$. Po publikacji artykułu kardynała pojawiły się liczne głosy krytyczne wobec stanowiska Kościoła w kwestii ewolucji, którego wyrazicielem, w opinii wielu, jest właśnie arcybiskup wiedeński. W odpowiedzi na te głosy, pochodzące nie tylko od ludzi spoza Kościoła, papież Benedykt XVI, wieloletni obrońca ortodoksji Kościoła katolickiego, zorganizował w Castel Gandolfo we wrześniu 2006 roku sympozjum poświęcone tematowi stworzenie - ewolucja. Na debatę Papież zaprosił swoich byłych uczniów (tzw. „Schülerkreis”)'. Sympozjum poprowadził kard. Schönborn, były student Benedykta XVI i zarazem jego bliski współpracownik. On też napisał przedmowę do publikacji Creation and Evolution. A Conference with Pope Benedict XVI in Castel Gandolfo ${ }^{3}$, będącej owocem wygłoszonych konferencji i toczących się po ich wygłoszeniu dyskusji. Nie było to jednak pierwsze sympozjum na temat ewolucji i jej relacji do stworzenia zorganizowane przez członków „Schülerkreis”. Ponad dwadzieścia lat wcześniej, w 1985 roku, odbyło się w Rzymie podobne tematycznie sympozjum, zatytułowane „Ewolucjonizm i chrześcijaństwo”, zorganizowane przez Roberta Spaemanna ${ }^{4}$. Gospodarzem była Kongregacja Nauki Wiary pod kierownictwem jej ówczesnego prefekta, kard. Josepha Ratzingera. Kard. Ratzinger napisał przedmowę do książki będącej owocem sympozjum ${ }^{5}$. Sympozjum w Castel Gandolfo z 2006 roku jest więc kontynuacją tego z 1985 roku.

W niniejszym artykule zaprezentujemy pokrótce poglądy reprezentatywnych przedstawicieli grupy „Schülerkreis”, będących cenionymi naukowcami, filozofami i teologami, biorących udział wraz z Benedyktem XVI w debacie w Castel Gandolfo. W szczególności przyjrzymy się poglądom dotyczącym tematu relacji stworzenie - ewolucja takich myślicieli jak kardynał Christoph Schönborn (arcybiskup Wiednia), Robert Spaemann (profesor filozofii) i Paul Erbrich (jezuicki ksiądz, profesor fizyki). Przedstawimy także stanowisko na interesujący nas temat innego uczestnika debaty z Benedyktem XVI, niebędącego członkiem „Schülerkreis”, Petera Schustera, profesora chemii, prezesa Austriackiej Akademii Nauk. W końcowej części artykułu przedstawimy reakcję wybranych autorów na poglądy $\mathrm{w}$ interesującej nas kwestii prezentowane przez wspomnianych przedstawi-

${ }^{1} \mathrm{Ch}$. Schönborn, Odnajdywanie zamystu $w$ przyrodzie, thum. P. Lenartowicz, „Filozoficzne Aspekty Genezy” 2/3 (2005/2006), s. 19-22; tenże, Finding Design in Nature, "The New York Times", http://www.nytimes.com/2005/07/07/opinion/07schonborn.html (dostęp: 20.05.2013).

„Schülerkreis” to grupa dawnych studentów Benedykta XVI, z którymi jeszcze jako kardynał odbywał regularne spotkania.

${ }^{3}$ Creation and Evolution. A Conference with Pope Benedict XVI in Castel Gandolfo, tłum. M.J. Miller, San Francisco 2008. Książka ta, poświęcona tematowi ewolucji, jest opatrzona przedmową kard. Schönborna, opracowaniami czterech uczestników debaty (kard. Christopha Schönborna, Petera Schustera, Roberta Spaemanna, Paula Erbricha), zapisem przebiegu dyskusji, a także dołączonym esejem autorstwa teologa Siegfrieda Wiedenhofera oraz uwagami biograficznymi i bibliograficznymi.

${ }^{4}$ Por. Ch. Schönborn, Foreword, w: Creation and Evolution, dz. cyt., s. 7.

${ }^{5}$ Evolutionismus und Christentum. Herausgegeben von Robert Spaemann, Reinhard Löw, Peter Koslowski, „Acta Humaniora”, Weinheim 1986, s. VII-IX. 
cieli grupy „Schülerkreis”, a w szczególności przez austriackiego kardynała, którego wypowiedzi budziły wśród komentatorów najwięcej kontrowersji.

\section{I. „SCHÜLERKREIS” O RELACJI STWORZENIE - EWOLUCJA NA TLE NAUCZANIA KOŚCIOŁA}

Kościół katolicki od dziesiątków lat odnosi się w swym nauczaniu do kwestii związanych $z$ ewolucją i jej relacją do stworzenia, a zwłaszcza do zagadnienia pochodzenia człowieka. Przypomnijmy więc najważniejsze wypowiedzi Kościoła odnośnie do tematu stworzenie - ewolucja.

Papież Pius XII w encyklice Humani generis (1950) podkreślił, że nie ma sprzeczności między teorią ewolucji a antropologią chrześcijańską ${ }^{6}$. Ojciec Święty uznał doktrynę ewolucjonizmu za wartościową hipotezę, godną namysłu, na równi z hipotezą przeciwną - kreacjonistyczną. Postawił jednak przy tym zasadniczy warunek: nie należy traktować tej hipotezy jako pewnik, bez potrzeby konfrontowania jej z tym, co mówi na ten temat Objawienie.

Prawie pół wieku po publikacji encykliki Piusa XII papież Jan Paweł II w liście do Papieskiej Akademii Nauk wyraził swoje stanowisko, że „teoria ewolucji jest czymś więcej niż hipotezą"ๆ. W tym przekonaniu utwierdza go fakt zyskiwania coraz większego uznania naukowców dla tej teorii w związ$\mathrm{ku} \mathrm{z}$ kolejnymi odkryciami dokonywanymi $\mathrm{w}$ różnych dziedzinach nauki. Zbieżność wyników niezależnych badań stanowi dla Ojca Świętego znaczący argument na poparcie tej teorii. Papież zwraca jednak uwagę na wieloznaczność określenia „teoria ewolucji”. Ta wieloznaczność skłania go do tego, by mówić nie tyle o teorii, ile raczej o teoriach ewolucji. Istnieją bowiem różne sposoby wyjaśniania mechanizmów ewolucji, a także różne filozofie, które stanowią ich punkt odniesienia. Ich ocena leży w kompetencji filozofii i teologii. Sama jednak chrześcijańska prawda o człowieku jest, jak podkreśla Jan Paweł II, nie do pogodzenia z tymi sposobami wyjaśniania mechanizmów ewolucji, które inspirowane są filozofią materialistyczną. Ojciec Święty wskazuje na różnicę natury ontologicznej, czy wręcz „skok” ontologiczny, z jakim mamy do czynienia w przypadku człowieka. Głosząc tezę o nieciągłości ontologicznej papież nie neguje ciągłości fizycznej, która stanowi nić przewodnią badań nad ewolucją. Zdaniem Jana Pawła II tylko wtedy, gdy w swych analizach odwołamy się zarówno do metod stosowanych w różnych dziedzinach nauk przyrodniczych, jak i metod właściwych dla filozofii i teologii, otrzymamy kompletną, pełną wizję człowieka. Nauki empiryczne badają i opisują różnorodne przejawy życia, co pozwala im określić zespół cech specyficznych dla istoty ludzkiej. Wskazanie momentu przejścia do sfery duchowej przekracza kompetencje nauk przyrodniczych. $\mathrm{W}$ tej sferze kompetentna staje się filozofia i teologia.

\footnotetext{
${ }^{6}$ Por. Pius XII, Encyklika ,Humani generis”, nr 28-30.

${ }^{7}$ Jan Paweł II, Przestanie Ojca Świętego do członków Papieskiej Akademii Nauk, 22 października 1996 roku, http://www.jezuici.krakow.pl/nw/doc/jp2ewolucja.htm (dostęp: 5.11.2012).
} 
Wątpliwości co do stosunku Kościoła katolickiego wobec teorii ewolucji rozwiał Benedykt XVI w czasie spotkania z „Schülerkreis” w Castel Gandolfo ${ }^{8}$. Podczas gdy pierwszy dzień spotkania był poświęcony dyskusji przygotowawczej wewnątrz „Schülerkreis”, Ojciec Święty osobiście uczestniczył w rozmowach w czasie całego drugiego dnia debaty ${ }^{9}$. Tocząca się na sympozjum dyskusja na temat stworzenia i ewolucji w dużej mierze ujawniła stanowisko papieża $\mathrm{w}$ interesującym nas temacie ${ }^{10}$.

Problemem dla Benedykta XVI nie jest kwestia wyboru między kreacjonizmem a teorią ewolucji ${ }^{11}$. Poglądów papieża na ewolucję nie należy więc ujmować $\mathrm{w}$ prosty schemat, że jest on „za” lub „przeciwko” niej. $Z$ jednej strony zauważa słabe strony teorii ewolucji, ale $\mathrm{z}$ drugiej nie utożsamia się z jej fundamentalistycznymi krytykami. Chodzi mu „o wzajemną interakcję różnych wymiarów, w których otwiera się również ścieżka wiary. Jeśli między ratio i fides podkreślamy scientia lub philosophia, wówczas stawką jest odzyskanie wymiaru rozumu [...]. Bez tego wymiaru wiara będzie ograniczać się do getta, a tym samym straci swoje znaczenie dla całej rzeczywistości i ludzkiej egzystencji”'12.

Benedykt XVI nie jawi się jako bezkrytyczny entuzjasta teorii ewolucji. Wręcz przeciwnie, jest nawet w stosunku do niej dość sceptyczny, uważając ją w niektórych punktach za niedostatecznie podbudowaną naukowo. W szczególności ważne dla Ojca Świętego jest przede wszystkim to, że w dużym stopniu teoria ewolucji nie może zostać potwierdzona doświadczalnie ${ }^{13}$. Istnieją znaczne luki w „materiale dowodowym”, z powodu ogromnej rozpiętości czasu, do której teoria ma odniesienie. Papież podkreśla, że teoria ta sugeruje pytania, które muszą być przypisane do filozofii. Same w sobie pytania te prowadzą poza wewnętrzny zakres nauk przyrodniczych ${ }^{14}$.

Benedykt XVI swymi wypowiedziami na interesujący nas temat potwierdza głoszone od dziesięcioleci stanowisko Kościoła, zgodnie z którym nie ma sprzeczności między chrześcijańską doktryną o stworzeniu a danymi nauk przyrodniczych ${ }^{15}$. Swoje powstanie i rozwój świat zawdzięcza „opatrznościowej mądrości Stwórcy”. Bóg jako Stwórca nieustannie podtrzymuje ten rozwój świata. Nauki przyrodnicze, jeśli ich wyniki są należycie interpretowane, coraz lepiej ukazują wyjątkowe miejsce, jakie zajmuje człowiek w Kosmosie.

${ }^{8}$ Ch. Schönborn, Foreword, w: Creation and Evolution, dz. cyt., s. 7. To było już drugie zaproszenie „Schülerkreis” do Castel Gandolfo od wyboru na papieża Benedykta.

${ }^{9}$ Tamże, s. 22.

${ }^{10}$ Tamże, s. 7-8.

11 Por. Pope Benedict XVI, Repetition of the lecture by Christoph Cardinal Schönborn: Fides, Ratio, Scientia, w: Creation and Evolution, dz. cyt., s. 161.

${ }^{12}$ Tamże, s. 161.

${ }^{13}$ Por. tamże, s. 161-162.

${ }^{14}$ Por. tamże, s. 162.

${ }^{15}$ Por. Benedykt XVI o ewolucji wszechświata pod okiem Opatrzności, http://info.wiara.pl/ doc/180192.Benedykt-XVI-o-ewolucji-wszechswiata-pod-okiem-Opatrznosci (dostęp: 8.11.2012). 


\section{DEBATA ,SCHÜLERKREIS” O RELACJI STWORZENIE - EWOLUCJA}

Po przypomnieniu najważniejszych wypowiedzi Kościoła w interesującym nas temacie zaprezentujemy pokrótce poglądy dotyczące ewolucji i jej relacji do wiary w ingerencję stwórczą Boga wybranych uczestników debaty w Castel Gandolfo.

\section{Kardynała Christopha Schönborna próba „uwolnienia” Darwina z darwinizmu}

Arcybiskup Wiednia, kard. Christoph Schönborn, w swych rozważaniach poświęconych kwestii stworzenie - ewolucja stawia sobie za cel uwolnić Darwina od darwinizmu, tzn. oczyścić go z ideologicznych nadinterpretacji materialistycznego poglądu na świat. Metropolita wiedeński przypomina, że zasadniczym celem najważniejszego dzieła Karola Darwina O powstawaniu gatunków było przedstawienie teorii, która miałaby wyjaśnić samoczynny rozwój roślin i zwierząt bez potrzeby odwoływania się do Stwórcy ${ }^{16}$. Darwin twierdził, że o powstaniu gatunków decydują przypadkowe mutacje i ich szanse na przeżycie ${ }^{17}$. Do tego nie są konieczne żadne odwoływania się do interwencji Stwórcy.

Teoria ewolucji stała się jednak dla wielu jej interpretatorów rodzajem światopoglądu, swoistą wizją świata. Zdaniem Schönborna właśnie ten ideologiczny składnik teorii Darwina jest głównym powodem, dla którego do dziś dyskusja o ewolucji i stworzeniu trwa i to z niesłabnącą siłą. Aby zapewnić większą przejrzystość w debacie nad stworzeniem i ewolucją, kardynał formułuje kilka postulatów ${ }^{18}$.

1) Należy odseparować prawdziwą naukę w teorii Darwina od jej ideologicznych składników.

2) Należy dopuścić do głosu obiektywną krytykę ideologicznych interpretacji darwinizmu.

3) Należy zapewnić dużo swobody w omawianiu otwartych kwestii w teorii ewolucji.

4) Aby umożliwić autentyczny postęp w debacie nad stworzeniem i ewolucją, należy poruszać się nie tylko na poziomie nauk przyrodniczych lub teologii, ale także pomiędzy nimi, w obszarze filozofii przyrody.

5) Należy rzeczowo i odpowiedzialnie szukać możliwych punktów stycznych między teorią ewolucji i doktryną katolicką.

\footnotetext{
${ }^{16}$ Por. Ch. Schönborn, Cel czy przypadek? Dzieło stworzenia i ewolucja z punktu widzenia racjonalnej wiary, oprac. H.Ph. Web er, tłum. M. Szczepaniak, Kielce 2009, s. 21.

${ }^{17}$ Por. tenże, Fides, Ratio, Scientia. The Debate about Evolution, w: Creation and Evolution, dz. cyt., s. 90.

${ }^{18}$ Por. tamże, s. $90-91$
} 
Schönborn wyraża więc swój zdecydowany sprzeciw wobec neodarwinowskich prób zakwestionowania celowości i projektu w przyrodzie ${ }^{19}$. Pisze: „Obecnie, na początku XXI stulecia, w obliczu roszczeń neodarwinizmu i wielorakich hipotez kosmologicznych, wymyślonych po to, by zignorować ogromną oczywistość celowości i projektu odnalezioną przez nowoczesną wiedzę przyrodniczą, Kościół katolicki znowu będzie bronił ludzkiego rozumu, głosząc, że wewnętrzny zamysł dostrzegany w przyrodzie nie jest złudzeniem. Teorie przyrodnicze, które usiłują wymknąć się tej oczywistości projektu, przywołując działanie «przypadku i konieczności», nie są wcale naukowe, lecz jak to ujął Jan Paweł II, są kapitulacją ludzkiej inteligencji”"20. Alternatywę dla „przypadku i konieczności” kardynał dostrzega tylko w „skrzyżowaniu się" własnej działalności stworzeń z umysłem Stwórcy, który ją podtrzymuje i umożliwia ${ }^{21}$.

Kardynał Schönborn w świecie istot żywych dostrzega liczne przykłady Boskiego projektu. Pisze: „Każdy system poglądów, który stawia sobie za zadanie zaprzeczenie lub zaproponowanie wyjaśnienia pomijającego przytłaczające dowody na rzecz projektu widocznego w świecie istot żywych, jest ideologią, a nie nauką"22. Dla arcybiskupa wiedeńskiego w pełni uzasadnionym jest stawiać pytanie o pochodzenie inteligentnego projektu, ujawniającego się w tym, co żywe ${ }^{23}$. Przestrzega jednak przed zbyt pochopnymi próbami doszukiwania się wszędzie ,inteligentnego projektu” ${ }^{24}$. Kardynał krytykuje także tych autorów, którzy optują za inną skrajnością - wcale nie dostrzegają ,„śladów” „inteligentnego projektu”. Jako przykład takiego skrajnie niewłaściwego, jego zdaniem, poglądu podaje stanowisko George’a V. Coyne'a, w stosunku do którego arcybiskup wiedeński nie szczędzi ostrych słów krytyki. Pisze m.in.: „Kiedy zatem astronom, a zarazem kapłan i teolog, posuwa się nawet do powiedzenia, że sam Bóg nie mógł wiedzieć z całkowitą pewnością, że w wyniku ewolucji powstanie człowiek [...], wygłasza się zupełne nonsensy"25.

\section{2. „Boska informacja zakodowana w stworzeniu”- ujęcie Roberta Spaemanna}

Filozof Robert Spaemann przedstawia swoją własną wizję relacji stworzenie - ewolucja. Już w przedmowie do książki Evolutionismus und Christentum zauważa, że paradygmat ewolucji rozwija się - w dużej mierze przez stale rosnącą literaturę popularno - naukową, najczęściej pióra biolo-

\footnotetext{
${ }^{19}$ Por. tenże, Cel czy przypadek?, dz. cyt., s. 163.

${ }^{20}$ Tenże, Odnajdywanie zamystu w przyrodzie, dz. cyt., s. 22.

${ }^{21}$ Por. tenże, Cel czy przypadek?, dz. cyt., s. 163.

${ }^{22}$ Tenże, Odnajdywanie zamystu w przyrodzie, dz. cyt., s. 19.

${ }^{23}$ Por. tenże, Cel czy przypadek?, dz. cyt., s. 158.

${ }^{24}$ Por. tenże, Odnajdywanie zamystu w przyrodzie, dz. cyt., s. 105.

${ }^{25}$ Tenże, Cel czy przypadek?, dz. cyt., s. 163.
} 
gów - do tzw. „ewolucyjnego poglądu na świat”26. Od materialistycznego poglądu na świat, który był z całą siłą propagowany na przełomie stuleci m.in. przez Ernsta Haeckela, ten pogląd odróżnia się większym wyważeniem i spójnością, a także większą zdolnością integracji pozornie niewspółmiernych wymiarów. Współdziałanie bezkierunkowej mutacji i selekcji, skonstruowane przez Darwina jako hipoteza, rozjaśniane jest obecnie, jak podkreśla Spaemann, z jednej strony przez wytłumaczenie procesów mutacyjnych poprzez odkrycie struktury genów, z drugiej zaś przez próbę rekonstrukcji działania selekcji. Podczas gdy tradycyjny materializm usiłował zdemaskować etyczną i religijną samoświadomość człowieka jako iluzję i bojowo ją zwalczał, biologiczny ewolucjonizm czuje się wystarczająco silny, by tę samoświadomość funkcjonalnie uzasadnić przez związane z tym zasady selekcji i zintegrować w całościowej koncepcji. Skutkuje to tym, że promotorzy ewolucyjnego punktu widzenia mają zasadniczo przyjazne nastawienie do religii.

W swym ujęciu procesu ewolucji Spaemann nie separuje się ani od nauki, ani też od naszego ludzkiego samozrozumienia ${ }^{27}$. Istnieją wstępne warunki dla rozwoju życia, dotyczące m.in. świadomości oraz samoświadomości. Jednak wstępne warunki nie są, zdaniem Spaemanna, wystarczającymi przyczynami. Nie wyjaśniają nam tego, kim jesteśmy. Aby w pełni zrozumieć, kim jest człowiek, zdaniem Spaemanna trzeba wyzwolić się od tych wstępnych warunków. Jedyną skuteczną próbę przezwyciężenia dychotomii idealistycznie - materialistycznie dostrzega w odwołaniu się do idei kreacjonizmu. Spaemann pisze przy tym, co należy rozumieć pod nazwą „kreacjonizm”: „Według tej idei proces naturalnego rozwoju życia oraz gatunków żywych stworzeń, w tym również ludzi, jest stworzony tą samą wolą Bożej Mądrości, co wynik tego procesu - mianowicie przyrodnicza istota, która odkrywa swoje pochodzenie i dziękuje Stwórcy za swoje życie, tj. swoją egzystencję. Ta sama Biblia, która mówi o bractwie wszystkiego, co żywe, z czym Bóg zawarł przymierze, mówi, że Bóg również żyje, a Jego życie jest światłością ludzi. Tak więc to życie poprzedza materię, ożywia ją"28.

Spaemann w swych rozważaniach zogniskowanych wokół zagadnienia stworzenie - ewolucja podejmuje także temat struktury żywego organizmu jako pochodnej zakodowanej $\mathrm{w}$ nim informacji. Według niego materialna konfiguracja istoty żywej może być nośnikiem zakodowanej informacji, ale nie tylko jej ${ }^{29}$. Informacja o funkcjonowaniu organizmu może być niewystarczająca, by umożliwić nam pełne zrozumienie rozwoju struktury materialnej. Spaemann nie wyklucza więc istnienie „drugiego kodu” zawierającego całkowicie różną informację. Możliwość istnienie „drugiego kodu”

\footnotetext{
${ }^{26}$ Por. R. Spaemann, Einführung, w: Evolutionismus und Christentum, dz. cyt., s. 1.

${ }^{27}$ Por. tenże, Common Descent and Intelligent Design, w: Creation and Evolution, dz. cyt., s. 67.

${ }^{28}$ Tamże.

${ }^{29}$ Por. tamże, s. 68.
} 
w strukturach żywych nie pozostaje, zdaniem Spaemanna, w sprzeczności z zasadą ekonomii myślenia. Wiara w Boga Stwórcę, jak podkreśla, daje człowiekowi specjalny „przywilej” poszukiwania informacji, która została zakodowana w całkowicie inny sposób, aniżeli ten, jaki wyznaczają nam metody nauk przyrodniczych ${ }^{30}$. Przyrodnik w swych badaniach fenomenu życia, niezależnie czy natknie się na to, co „dobre”, „piękne” i „święte”, zawsze będzie miał do czynienia $\mathrm{z}$ prawdą wynikającą $\mathrm{z}$ teorii naukowej. Jednak skąd pochodzi piękno i co to oznacza, że coś jest piękne, to będzie w stanie zrozumieć wyłącznie przy pomocy informacji, którą Bóg zakodował w swym dziele.

\section{3. „Przypadek czy cel w procesie ewolucji?” - stanowisko Paula Erbricha}

Paul Erbrich, jezuita i profesor fizyki, zauważa, że w debacie o stworzeniu i ewolucji bardzo często pomija się niezwykle ważne, jego zdaniem, rozróżnienie między faktem ewolucji a przyczyną lub przyczynami ewolucji ${ }^{31}$. Interpretujemy ,ewolucję" jako ciągłą linię potomków od pierwszego organizmu aż do człowieka. Poza rozwojem niedawnych odmian i ras nikt nie był w stanie bezpośrednio zaobserwować takiego związku. Zostało to wydedukowane na podstawie dowodów. Ilość dowodów ciągle się zwiększała przez ostatnie dwieście lat. Równocześnie przedział czasowy, w którym wyższe, wielokomórkowe organizmy się rozwijają, urósł do ponad pięciuset milionów lat. $\mathrm{Z}$ tych względów bezwzględna większość biologów jest przekonana, jak zauważa Erbrich, że ewolucja obejmuje wszystkie żyjące istoty. Dla nich jest to coś więcej niż tylko hipoteza. Ogromna ilość biologicznych faktów w oczach biologów staje się zrozumiała, znacząca, spójna oraz logiczna tylko w świetle ewolucji. To czy hipoteza o ewolucji może być poprawnie nazywana teorią, odnośnie do której nie może być żadnych logicznych wątpliwości, zależne jest od tego, czy grupa wystarczających przyczyn przywołujących i utrzymujących ewolucję może być naprawdę uznana i udowodniona ${ }^{32}$.

Erbrich uważa, że większość współczesnych biologów jest przekonana, że decydująca przyczyna ewolucji została odnaleziona ${ }^{33}$. Jest to mechanizm przypadku i doboru naturalnego Darwina, poparty odkryciami z genetyki populacji ${ }^{34}$. Zdaniem Erbricha mechanizm ten może nie być jednak jedyną przyczyną, choć przyznaje, że jest przyczyną fundamentalną i najistotniejszą. Wielu biologów nie może zrozumieć, jak ktokolwiek może być za ewolucją, będąc jednocześnie przeciwnikiem mechanizmów ewolucyjnych Darwina. Dla nich mechanizm przypadku oraz selekcji naturalnej jest nieroze-

\footnotetext{
${ }^{30}$ Por. tamże, s. 69.

${ }^{31}$ Por. P. Erbrich, The Problem of Creation and Evolution, w: Creation and Evolution, dz. cyt., s. 70

${ }^{32}$ Por. tamże, s. $70-71$

${ }^{33}$ Por. tamże, s. 71

${ }^{34}$ Por. tamże, s. 72.
} 
rwalnie połączony z istnieniem ewolucji. Jest dla nich oczywiste, że jeżeli ktoś jest „na tak” w kwestii ewolucji, to będzie również „na tak” w stosunku do mechanizmów Darwina. Każdy, kto poddaje te mechanizmy w wątpliwość, poddaje tym samym w wątpliwość fakt ewolucji, a co za tym idzie, musi być kreacjonistą, „który zakłada, przynajmniej w przypadku pierwszych gatunków stworzonych na podstawie fundamentalnego planu, że pewnego dnia pojawili się w pełni uformowani na bujnej łące, zaczęli się obwąchiwać, a następnie przeszli do reprodukcji” ${ }^{35}$.

Erbrich zauważa, że chociaż biolodzy zbadali czynnik doboru naturalnego w najdrobniejszych szczegółach, często przy tym jednak pomijają fakt, że selekcja zakłada celowość w żywych stworzeniach. Pisze: „Żywe stworzenia muszą czegoś «chcieć». Jeżeli nie chcą niczego, jeżeli do niczego nie dążą (do takich rzeczy, na przykład, jak przetrwanie czy reprodukcja), to nie ma żadnej rywalizacji, ani też walki o ograniczone surowce" ${ }^{36}$. Jeśli nie ma rywalizacji, wtedy nie ma też selekcji tych bardziej skutecznych. Kontynuuje więc: „Płatki śniegu, które odkładają się na stokach narciarskich nie chcą niczego, nie posiadają żadnych potrzeb ani celów, «chciałyby» jedynie leżeć na wzgórzach. Jest im wszystko jedno, czy ruszą w dół w postaci lawiny, czy stopią się bezpośrednio na stokach na wiosnę. Pomiędzy poszczególnymi płatkami śniegu nie dochodzi do żadnej rywalizacji ani selekcji. Nie opracowują żadnego urządzenia, które pozwoliłoby im zmniejszyć tarcie między nimi a podłożem, tak aby miały szansę ruszyć w dół szybciej niż ich najbliżsi rywale"37.

Erbrich podkreśla, że jest niewiele badań wśród biologów w kwestii „przypadku”. Najczęściej biolodzy mówią w taki sposób, jakby dla wszystkich było oczywiste, co jest rozumiane przez przypadek. Pisze: „Dla biologów przypadek zdaje się ostatecznie znaczyć: arbitralne przyczyny, najpierw te, później tamte, w każdym razie jednak brak jakiegokolwiek planu czy projektu, jakiegokolwiek działania skierowanego na dany cel czy intencję. Jest to uważane za coś całkowicie aksjomatycznego. Biologia powinna być wolna od teleologii w takim samym stopniu, jak komputer ma być wolny od wirusów”38. Tam, gdzie naukowcy nie mogą się obejść bez „celowych działań", odwołują się do teleonomii, jako przeciwieństwa teleologii. Erbrich precyzuje, co rozumie pod terminem „teleonomia”: „Żywe istoty z pewnością dążą do określonych rzeczy, jednak jedynie w taki sposób, w jaki robią to samonaprowadzające się rakiety przeciwlotnicze. Tak naprawdę, nie dążą do nich, a jedynie symulują to dążenie. Wiemy, że rakiety przeciwlotnicze symulują dążenie, ponieważ to my je budujemy. Wiemy, że żywe istoty naprawdę do czegoś dążą, ponieważ my również jesteśmy żywymi istotami i sami również doświadczamy dążenia do określonych rzeczy, niekiedy na-

\footnotetext{
${ }^{35}$ Tamże.

${ }^{36}$ Tamże, s. 72-73.

${ }^{37}$ Tamże, s. 73.

${ }^{38}$ Tamże.
} 
wet zanim jeszcze postawimy sobie świadomie określone cele" ${ }^{\text {"39 }}$. Jeżeli jest jakaś celowość, to wtedy nie ma powodu odnoszenia się do przypadku ${ }^{40}$.

Dla Erbricha uderzające jest to, że celowe struktury zachodzą jedynie w sferze istot żywych, w biosferze ${ }^{41}$. Cała ludzka technologia także należy do tej sfery. Poza niezależnym życiem nie ma nawet śladu celowości, jest tam co najwyżej użyteczność na potrzeby biosfery. Niezależnie od tego, czy mowa o celowości czy „funkcjonalności”, to rzeczy, które im podlegają, nie dążą do niczego. Pisze: „Celem oka nie jest osiągnięcie celu, który by samo sobie narzuciło - nie ma w tym żadnej dynamicznej teleologii. Celem jest ostatecznie intencja żywego stworzenia, które chce przy pomocy swoich oczu widzieć. Poza tym Bóg jako Stwórca, chociaż istnieje, wciąż jednak jest całkowicie ukryty. Może być tak, że by uznać istnienie celowości, to musi być ktoś, kto te cele ustali, jednak to nie zakłada jego istnienia. Dowód, że istnieją celowe struktury, same z siebie, pozostawia otwarte pytanie odnośnie tego, co je stworzyło"

4. „Ewolucja nie wymaga zewnętrznej interwencji” - ujęcie Petera Schustera

Na debatę do Castel Gandolfo Benedykt XVI zaprosił Petera Schustera, niezwiązanego ze środowiskiem „Schülerkreis”. Chemik, twórca koncepcji hipercykli o powstaniu życia z materii nieożywionej, i zarazem prezes Austriackiej Akademii Nauk, w swych rozważaniach zaprezentowanych podczas debaty z Ojcem Świętym broni tezy, że ewolucja działa według praw natury i nie potrzebuje żadnej zewnętrznej interwencji ${ }^{43}$. Co więcej, nie znajduje ani jednego faktu z obszaru nauk przyrodniczych, który mógłby być całkowicie wyjaśniony jedynie ingerencją Nadprzyrodzonej Istoty. Dla Schustera jest oczywiste i nieuniknione założenie biologii ewolucyjnej, że interwencja Istoty Nadprzyrodzonej, gdyby miała zaistnieć, nie może być nawet obiektem naukowych spekulacji. W podobny sposób interpretują, jak podkreśla, proces rozwoju Kosmosu aż do uformowania naszej Ziemi dziedziny, takie jak astrofizyka i kosmologia. Rozwój, od Wielkiego Wybuchu aż do uformowania się istoty ludzkiej, dla Schustera wydaje się zjednoczonym, kosmicznym działaniem. Schuster znajduje jednak miejsce na zbudowanie mostu między naukami przyrodniczymi a teologią. Pisze: „To, co mnie porusza i fascynuje, to relatywnie wąski wachlarz wielości wszystkich możliwych światów, w których drogi prowadzą od początku naukowej idei o Wielkim Wybuchu do obecnego Kosmosu. Moi przyjaciele, którzy są kosmologami, mówią mi, że niewielka zmiana w naturalnej ciągłości doprowa-

\footnotetext{
${ }^{39}$ Tamże, s. 73-74.

${ }^{40}$ Por. tamże, s. 76

${ }^{41}$ Tamże, s. 79.

${ }^{42}$ Tamże, s. 81.

${ }^{43}$ Por. P. Schuster, Evolution and Design A Review of the State of the Art in the Theory of Evolution, w: Creation and Evolution, dz. cyt., s. 58.
} 
dziłaby do całkowicie innych światów. Biologiczna lub chemiczna ewolucja na Ziemi potrzebuje relatywnie niedużych amplitud temperatur, a rozwinięcie biosfery, rozumianej jako biologiczna ewolucja od jednej oryginalnej struktury życia aż do istoty ludzkiej, przeszła przez liczne «oczka igły», które były określone przez warunki klimatyczne oraz inne warunki środowiskowe. Zakończone sukcesem wzajemne odziaływanie tych wielu warunków wydaje się dla mnie niezwykle istotne. Według mnie, to właśnie w tym miejscu mogło dojść do interwencji w przebiegu biologicznej ewolucji i tutaj właśnie jest miejsce na zbudowanie mostu pomiędzy teologią a naukami przyrodniczymi”, ${ }^{44}$.

\section{OCENA WKŁADU „SCHÜLERKREIS” W DEBATĘ O RELACJI STWORZENIE - EWOLUCJA}

„Schülerkreis" swymi poglądami na ewolucję wywołał ożywioną dyskusję w różnych środowiskach, zarówno w samym Kościele, jak i poza nim. Najwięcej kontrowersji wzbudziło stanowisko arcybiskupa wiedeńskiego.

Dla Daryla P. Domning, autora recenzji Creation and Evolution, debata „Schülerkreis” o relacji stworzenie - ewolucja jest podwójnym rozczarowaniem $^{45}$. Zdaniem tego autora niektórzy członkowie „Schülerkreis” zdają się iść w stronę ,inteligentnego projektu” - i to, w jego ocenie, jest godne pożałowania. Jeszcze bardziej niepokoi go to, że badacze ci sprawiają wrażenie nieświadomych bardziej odpowiednich i przemyślanych koncepcji w swoim własnym Kościele.

Domning podkreśla, że publikacja Creation and Evolution skupia uwagę na przedstawieniu poglądów nie tyle Benedykta XVI, ile przede wszystkim stanowiska wiedeńskiego kardynała. W ocenie Domninga to właśnie Schönborn zdominował dyskusję z 2006 roku, a jego kontrowersyjne opinie mogą w większym stopniu ukazać opinii publicznej sposób myślenia obowiązujący w wewnętrznych kręgach Watykanu. Ostrze krytyki kieruje więc wspomniany autor przede wszystkim w stronę kardynała. Pisze: „Schönborn wyraźnie uczył się biologii z dzieł kreacjonistów. Powtarza brednie mówiące, że «brakujące ogniwa [...] po prostu nie istnieją»; gady nie mogły po prostu przeistoczyć się w ptaki poprzez «niezliczone małe mutacje», «przetrwanie najsprawniejszych» jest problematyczne, ponieważ przetrwanie jest często kwestią szczęścia, co za tym idzie, zaakceptowanie ewolucji musi być podyktowane ideologią"46. Swoją niezwykle krytyczną ocenę poglądów „Schülerkreis” kończy słowami: „Nie osiągnięto nic nowego w Castel Gandolfo. [...] Schönborn i inni przedstawiciele tradycyjnej filozofii Kościoła są tylną, nie zaś przednią strażą katolickiego ewolucyjnego myślenia. Wśród

44 Tamże, s. 58-59.

45 Por. D.P. Domning, Review: Creation and Evolution: A Conference with Pope Benedict XVI, „Nation Center for Science Education” 3 (28) (2008), s. 25-27, http://ncse.com/ $\mathrm{rncse} / 28 / 3 /$ review-creation-evolution-conference-with-pope-benedict-xvi (dostęp: 7.11.2012).

${ }^{46}$ Tamże. 
tych prałatów i ich konserwatywnych zwolenników starożytne scholastyczne pojęcie niezmiennych «esencji» rzeczy jest wciąż niejasne, i niemal całkowicie wyklucza ewolucyjny paradygmat. Pojęcie «emergentne cechy» nie pojawia się nigdzie w tej książce, tak jak i brakuje tam współczesnych katolickich ewolucyjnych teologów pokroju Johna Haught i Denisa Edwardsa. Współpracownicy papieża, widocznie nieświadomi innych form teistycznej ewolucji, zostali pchnięci w stronę inteligentnego projektu dlatego, że strona optująca za ewolucją jest zdominowana przez ateistów, takich jak Richard Dawkins. Jest to zrozumiałe, jednak zarazem tragiczne, ponieważ teologowie w swoim własnym Kościele dysponują lepszymi rozwiązaniami tych problemów niż te, których nauczyli się w szkole lub zapożyczyli od relatywnie im obcego ruchu ID",47.

Na poglądy kardynała Schönborna ostro zareagował także m.in. jezuita, George V. Coyne. Wypowiedzi arcybiskupa Wiednia, w ocenie Coyne'a, znacząco osłabiają z trudem wypracowany przez Jana Pawła II przyjazny dialog Kościoła ze społecznością naukowców ${ }^{48}$. Coyne protestuje przeciwko marginalizowaniu ,epokowego” listu Jana Pawła II. Zdaniem byłego dyrektora Watykańskiego Obserwatorium Astronomicznego Schönborn chce pokazać, że Kościół pod przewodnictwem Benedykta XVI opanował niezrozumiały lęk przed „najlepszymi” osiągnięciami współczesnej nauki.

\section{ZAKOŃCZENIE}

W zasadniczych kwestiach zorientowanych na interesujący nas temat relacji teorii ewolucji do wiary w Boga Stwórcę badacze skupieni wokół Josepha Ratzingera wyrażają zbieżne stanowisko. Przede wszystkim nie zgadzają się z rozumieniem ewolucji w sensie neodarwinowskim, jako niekierowany i nieplanowany proces powstawania przypadkowych zmian. Wspomniana jednomyślność w ocenie teorii ewolucji i jej relacji do stworzenia, będąca wyrazem jedności ideowej środowiska „Schülerkreis”, nie u wszystkich uczonych i myślicieli identyfikujących się z Kościołem katolickim znajduje uznanie. Całkowicie odmienne stanowisko przyjmuje, dla przykładu, wspominany już jezuita George V. Coyne, który akceptuje rolę przypadku w ewolucji, widząc w nim swoistą metodę Boskiego stwarzania. We Wszechświecie dostrzega działanie zasadniczo trzech procesów: przypadku, konieczności i płodności Wszechświata. Zdaniem uczonego jezuity płodność Wszechświata oraz współdziałanie w nim przypadku i konieczności odpowiada za kierunkowość procesu ewolucji. Osiągnięcia współczesnej nauki i współczesnych badań biblijnych domagają się, jak zauważa Coyne, by odrzucić pojęcie „Boga Projektanta”. Relacja Boga do stworzenia przy-

${ }^{47}$ Tamże.

${ }^{48}$ Por. G.V. Coyne, Przypadek jako metoda Boskiego stwarzania, tłum. D. Sagan, „Filozoficzne Aspekty Genezy” 2/3 (2005/2006), s. 39-44, http://www.nauka-a-religia.uz. zgora.pl/index.php?action=tekst\&id=91 (dostęp: 24.03 .2013$)$. 
pomina, jak twierdzi, relację rodzica do dziecka. Pisze: „Bóg działa we Wszechświecie. Wszechświat ma pewną własną witalność, podobnie jak dziecko. Ma on zdolność reagowania na czułe i krzepiące słowa. Gdy dziecko trzymane jest w dyscyplinie, zachowujemy i wzbogacamy jego indywidualny charakter i jego własną pasję życia. Rodzic musi pozwolić dziecku dorosnąć, by dokonywało swoich własnych wyborów i by w życiu podążało własną drogą. Słowa dające życie są bogatsze niż rozkazy i informacja. Możemy sobie wyobrazić, że Bóg zajmuje się Wszechświatem, posługując się takimi właśnie sposobami”, ${ }^{49}$. W innym miejscu dodaje: „Bóg pozwala światu być takim, jakim się staje w swojej ciągłej ewolucji. On nie interweniuje bez przerwy, ale raczej pozwala, uczestniczy, kocha" ${ }^{\text {"50 }}$.

„Schülerkreis" - ideowo i organizacyjnie zintegrowanej grupie naukowców, filozofów i teologów - należy się bez wątpienia szacunek ze względu na regularnie podejmowany przez niego wysiłek organizowania i prowadzenia debat naukowych wokół aktualnych i ważnych dla Kościoła tematów, zwłaszcza $\mathrm{z}$ obszaru relacji nauka - religia. $\mathrm{Z}$ uznaniem należy przyjąć także fakt zapraszania na organizowane debaty badaczy niezwiązanych ze środowiskiem „Schülerkreis”, jak choćby wspomnianego Petera Schustera, twórcy koncepcji hipercykli, który w ocenie teorii ewolucji i jej relacji do stworzenia wyraża radykalnie odmienne stanowisko. Ta otwartość na inne rozstrzygnięcia $\mathrm{w}$ omawianym temacie wydaje się jednak tylko pozorna, nie skłania bowiem członków „Schülerkreis”, zwłaszcza kardynała Schönborna, do jakiejkolwiek rewizji swojego stanowiska wobec teorii Inteligentnego Projektu, którą z punktu widzenia metodologii nauk należy ocenić jednoznacznie negatywnie. „Schülerkreis”, pomimo posiadania wielu niewątpliwych walorów, nie może być więc wzorem dla innych podobnych grup wewnątrz Kościoła a także poza nim, którym to grupom zawsze ma przyświecać jeden zasadniczy cel - uczciwe poszukiwanie prawdy.

\section{THE CATHOLIC FAITH IN CREATION AND THE THEORY OF EVOLUTION: CONFLICT OR SYMBIOSIS? JOSEPH RATZINGER'S “SCHÜLERKREIS” DEBATE ON THE TOPIC OF THE CREATION - EVOLUTION RELATION}

\section{Summary}

In September 2006 in Castel Gandolfo, at a symposium organized by Pope Benedict XVI, there was certain debate around the topic of creation - evolution. The Pope invited his former students and seminarians - the so-called "Schülerkreis", with whom, as Cardinal, he held regular meetings, to participate. The debate in Cas-

\footnotetext{
${ }^{49}$ Tamże.

${ }^{50}$ Tamże.
} 
tel Gandolfo involved, among others: Cardinal Christoph Schönborn (Archbishop of Vienna), Robert Spaemann (professor of philosophy) and Paul Erbrich (Jesuit priest, professor of physics). Also Peter Schuster, professor of chemistry, president of the Austrian Academy of Sciences, not associated with the "Schülerkreis" circles, was invited to join the discussion. In this article, the views of the above-mentioned participants in the debate in Castel Gandolfo are briefly presented. The response of selected authors to the views on the issues of concern as presented by the representatives of the "Schülerkreis" group, where, in particular, the Austrian cardinal's speech aroused the most controversy.

Keywords:

creation, evolution, "Schülerkreis" 